\title{
Aspek Sosial Pada Tokoh Utama Dalam Cerpen Mahou Hakase
}

\author{
Azimatusy Syahidah*, Idah Hamidah, Eko Kurniawan \\ Program Studi Sastra Jepang, Universitas Jenderal Soedirman, Purwokerto, Indonesia
}

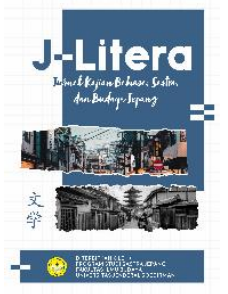

\begin{abstract}
This research in entitled "The Social Aspects of the Main Characters in Mahou Hakase Short Stories". The purpose of this research is to know the social aspects including habitus, capital, domain, and practice of the main character named Genko Sensei in the short story of Mahou Hakase by Iwaya Sazanami. The theory used is the theory of literary sociology popularized by Pierre Bourdieu regarding habitus, capital, domain, and practice. This research uses descriptive qualitative research methods as well as data collection by referring to and taking notes. The data used in the form of paragraphs, sentences, and dialogs in the short story. The results of this study found 38 sosial aspects including 7 habitus, 11 capital, 4 domains, and 16 practices owned by Genko Sensei. Habitus that he had was a good relationship, considered to be good and honest, and able to change bad habits into good. This he combined with capital held in the form of money, a college degree, public speaking skills, do not hesitate to act, confident, good cooperation skills and magic abilities. By utilizing the habitus and capital, Genko Sensei able to do a lot of practice (such as lingers though without legs, grow horns to fight the enemy, and others) to master the realm of Germany, the University, and the Palace. In the end, he was able to become famous, get a degree, defeat the enemy, gain power by winning the hearts of the King at the palace, and received a lot of gifts. Above aligned with Pierre Bourdieu's theory about the relationship habitus, capital, and domains, resulting in practice to seize power.

Keywords:

Habitus; capital; domain; practice; Mahou Hakase

Article Info:

First received:

19 November 2019

Available online:

30 November 2019
\end{abstract}

\section{PENDAHULUAN}

Sastra merupakan satu dari sepuluh kateori besar yang masuk ke dalam klasifikasi desimal yang ditemukan sekitar delapan puluh tahun yang lalu oleh ahli perpustakaan Amerika yakni Melvil Dewey (Escarpit, 2005: 21). Sastra menurut Robert Escarpit didefinisikan sebagai sebuah kristalisasi keyakinan, nilai-nilai, serta norma-norma yang telah disepakati bersama oleh suatu masyarakat. Setiap negara memiliki kekhasan dalam bidang sastra. Di negara Jepang dikenal istilah kesusastraan Jepang. Istilah kesusastraan secara umum muncul pertama kali pada tahun-tahun terakhir sekitar abad ke-XVIII (Escarpit, 2005: 5).

Dalam dunia kesusastraan Jepang, selama hampir 50 tahun pendidikan bahasa Jepang di Perguruan tinggi di Indonesia berlangsung, ternyata jumlah karya sastra Jepang yang dipublikasikan di Indonesia tidak lebih dari 50 judul buku (Purnomo, 2010: ix). 
sosiologi sastra Pierre Bourdieu meliputi habitus, modal, ranah, dan praktik. Penelitian ini akan membahas habitus, modal, ranah, dan praktik yang dimiliki tokoh utama sehingga ia dapat memperoleh kekuasaan.

\section{KAJIAN TEORI}

\section{Cerpen}

Menurut Kamus Besar Bahasa Indonesia (Wahyu, 2013:59) cerpen adalah karangan pendek (kurang dari 10.000 kata) yang memberikan kesan tunggal dan memusatkan diri pada satu tokoh dalam satu situasi. Sementara J.S Badudu (1975:53) menyebutkan bahwa cerpen merupakan cerita yang berpusat pada suatu peristiwa atau kejadian yang menumbuhkan peristiwa itu sendiri.

\section{Tokoh dan Penokohan}

Istilah tokoh mengacu pada orang yakni pelaku cerita (Andri Wicaksono, 2014: 172). Andri Wicaksono (2014 :171) bahwa tokoh adalah pelaku cerita, sedangkan penokohan adalah sifat yang dilekatkan pada diri tokoh, penggambaran atau pelukisan mengenai tokoh cerita, baik lahirnya maupun batinnya oleh seorang pengarang.

\section{Sosiologi Sastra Pierre Bourdieu}

\section{Habitus}

Habitus merupakan teori yang dipopulerkan oleh seorang sosiolog sekaligus antropolog yang pada masa akhir hidupnya dikenal dalam pergerakan anti-globalisme yakni Pierre Bourdieu. Habitus dapat diartikan sebagai "struktur mental atau kognitif" yang menjelaskan hubungan manusia dengan dunia sosial (Ritzer, 2012: 581). Habitus dianalogikan sebagai struktur sosial yang kemudian diinternalisasikan lalu diwujudkan dan diaplikasikan. Salah satu contohnya merupakan kebiasaan makan dengan menggunakan tangan kanan, yang sudah dipelajari seseorang sejak kecil sehingga kebiasaan ini terbawa sampai dewasa. Hal tersebut dapat terjadi dikarenakan kebiasaan tersebut sudah diinternalisasikan ke dalam dirinya.

Habitus pada dasarnya yang mendasari beroperasinya individu dalam suatu arena agar memperjuangkan posisinya (Zamhuri, 2016: 293). Habitus memberikan petunjuk kepada manusia mengenai bagaimana dunia bekerja, bagaimana cara mengevaluasi berbagai hal dan peristiwa, serta mampu memberikan pedoman atau petunjuk pelaksana terhadap sebuah tindakan. Bourdieu mengatakan bahwa manusia pada hakikatnya akan dibimbing segala tindakannya oleh skema-skema tersebut.

Akan tetapi, perlu diketahui bahwa manusia tersebut bukanlah instrumen, karena habitus pada dasarnya tidak memiliki pikiran dan kreativitas seperti manusia itu sendiri. Bourdieu menegaskan bahwa habitus bukanlah penciptaan asli individu; juga bukan individu yang bebas dari kondisi-kondisi struktur sosialnya. Melainkan, habitus merupakan sebuah "produk" dari kondisikondisi struktural sosial dari individu. (Fashri, 2014: xii). Habitus membimbing seorang manusia atau individu untuk memahami, menilai, mengapresiasi tindakan mereka berdasarkan pada skema atau pola yang dipancarkan dunia sosial.

Pernyataan ini sesuai dengan apa yang dijelaskan Bourdieu tentang habitus. Habitus menghasilkan perbedaan gaya hidup dan praktik-praktik dalam kehidupan. Skema ini diperoleh dari pengalaman individu dalam berinteraksi dengan individu-individu lain maupun lingkungan di mana ia berada dalam sebuah lingkungan masyarakat (Fashri, 2014: 99). Habitus dibagi menjadi 3, yaitu habitus berdasarkan ruang adaptasi, habitus berdasarkan sifat perilaku, dan berdasarkan struktur mental (kognitif). Berdasarkan runag adaptasi, habitus memberikan ruang bagi seorang individu untuk dapat beradaptasi dengan hal-hal yang ada di sekitarnya. Habitus merupakan struktur yang dapat dibentuk kehidupan sosial (Structured 
Structure) dan juga struktur yang membentuk kehidupan sosial (Structuring Structure).

Berdasarkan sifat perilaku, habitus dibagi menjadi dua yakni habitus yang bersifat ajeg dan habitus yang dapat berubah menjadi lentur karena proses adaptasi. Sedangkan berdasarkan struktur mental (kognitif), habitus diklasifikasikan menjadi dua jenis yakni hubungan antar manusia dan hubungan dengan dunia atau lingkungan sosialnya.

\section{Modal}

Modal menurut Bourdieu diklasifikasikan menjadi dua yakni berdasarkan jenis dan berdasarkan sifat akumulasinya. Modal berdasarkan jenis meliputi modal ekonomi, sosial, budaya, dan modal simbolik. Modal berdasarkan sifat akumulasinya dapat dibedakan menjadi dua, yakni modal dapat bertambah dan modal dapat berkurang.

Modal yang bertambah akan menyebabkan seorang individu mampu menguasai ranah dan meningkatkan posisinya di dalam masyarakat sehingga ia dapat melakukan berbagai macam praktik sosial. Sebaliknya, modal yang berkurang akan menyebabkan terancamnya seorang individu dalam mempertahankan posisinya dan sulit menguasai ranah sehingga menyebabkan individu tersebut gagal melakukan praktikpraktik sosial di lingkungan masyarakatnya.

\section{Ranah}

Ranah dapat artikan sebagai arena, tempat, maupun dapat dianalogikan sebagai ring tinju bagi individu untuk dapat mempertahankan posisinya atau bahkan menaikan jenjangnya. Berbeda dengan latar tempat, ranah lebih spesifik mengacu pada tempat di dalamnya terjadi perebutan modal antara satu individu dengan individu yang lain.

\section{Praktik}

Praktik merupakan upaya yang dilakukan untuk memperoleh kekuasaan. Praktik bisa diperoleh dengan memanfaatkan habitus dan modal yang dimiliki sehingga mampu menguasai ranah guna memperoleh, memperluas, ataupun mempertahankan kekuasaan di dalam masyarakat. Dengan demikian, mereka yang mampu mengkolaborasikan habitus dan modal akan mampu melakukan praktik untuk menguasai ranah dan memperoleh kekuasaan.

\section{METODOLOGI PENELITIAN}

Dalam penelitian ini penulis menggunakan jenis penelitian deskriptif kualitatif yakni sumber data yang digunakan adalah karya dan naskah yaitu cerpen. Penelitian yang dilakukan menggunakan pendekatan sosiologi sastra Pierre Bourdieu, yakni melalui aspek sosial yang pasti ada dalam setiap karya sastra. Data yang diteliti adalah potongan teks, baik berupa kalimat, paragraf, maupun dialog tokoh utama. Sumber data yang digunakan dalam penelitian ini yaitu cerpen karya Iwaya Sazanami berjudul "Mahou Hakase" atau yang dalam bahasa Indonesia disebut sebagai Doktor Sihir. Untuk memenuhi pencapaian penelitian, penulis menggunakan teknik pengumpulan data dengan teknik simak catat.

Data yang telah dikumpulkan dan diklasifikasi akan dilakukan pengkodean. Contoh: (Dt.38/Hlm227/P62). "Dt. 38" merupakan singkatan dari "Data ke-38", angka 38 merupakan urutan penemuan data. "Hlm227" menjelaskan bahwa data tersebut berada di halaman "ke-227" pada sumber data. Sementara "P62" mendefinisikan "Paragraf ke-62". Tidak hanya menggunakan huruf "P" sebagai singkatan dari "Paragraf", penulis juga menggunakan huruf lain yaitu " $K$ " untuk data yang berbentuk "kalimat" dan huruf " $D$ " untuk data yang berbentuk "Dialog". Contoh lainnya adalah: (Dt.11/Hlm219/K12) yang dapat dibaca; data ke 11, halaman 219, kalimat ke-12.

Dalam analisis data, penulis menggunakan metode analisis hermeneutika Paul Ricouer. Ratna (2013:46) menjelaskan 
bahwa di setiap karya sastra terdapat ruangruang kosong. Maka, ruang-ruang kosong itulah yang dibebaskan kepada pembaca untuk memberikan berbagai penafsiran.

\section{HASIL DAN PEMBAHASAN}

Berdasarkan hasil penelitian ini terdapat 38 data aspek sosial yang ditemukan meliputi 7 habitus, 11 modal, 4 ranah, dan 16 praktik.

\section{Habitus}

Habitus yang ditemukan dalam penelitian berjumlah 7 data, yaitu sebagai berikut:

\section{Structured Structure}

Konteks Data: Genko Sensei merupakan seorang anak yang pada suatu waktu diangkat sebagai anak angkat oleh pamannya. Namun tak lama kemudian pamannya meninggal dan ia pun mendapat seluruh harta warisan sang paman. Hal tersebut membuatnya kaya raya sehingga ia sangat gembira. Berikut data yang ditemukan:

1)遂にはその嬉しまぎれに、学問 の方は放棄てしまって、お酒を 飲むやら、賭博を打つやら、悪 い遊興ばかりして。

Tsui ni wasono ureshi magire ni, gakumon no kata wa houkite shimatte, osake o nomu yara, tobaku o utsu yara, warui yuukyou bakarishite.

'Namun akhirnya, kerena terlalu gembira, ia meninggalkan kegiatan belajarnya dan meminum minuman keras, berjudi, dan hanya melakukan hal-hal yang buruk.'

(Dt.7/Hlm219/P5)

Dijelaskan dalam konteks data di atas bahwa Genko Sensei merupakan seorang anak yang diangkat menjadi anak angkat oleh pamannya dan saat pamannya meninggal, ia mendapatkan seluruh harta warisan sang paman. Ia pun menjadi kaya raya. Harta yang ia dapatkan membuatnya sangat gembira.

Berdasarkan paragraf pada data 7 tersebut, diceritakan bahwa ia menjadi begitu gembira (seperti yang telah dijelaskan dalam konteks data bahwa hartalah yang membuatnya begitu gembira), ia kemudian berubah memiliki kebiasaan yang buruk seperti kebiasaan meminum minuman keras, berjudi, dan hanya melakukan hal-hal yang buruk. Hal tersebut ditunjukkan pada kutipan data yang digarisbawahi yakni: ... Osake o nomu yara, tobaku o utsu yara, warui yuukyou bakarishite. '... Meminum minumminuman keras, berjudi, dan hanya melakukan hal-hal yang buruk.'

Kebiasaan tersebut terjadi dikarenakan faktor dari luar yaitu harta yang berlimpah yang membuatnya terpengaruh hingga akhirnya harta tersebut mengubah kebiasaan Genko Sensei. Sebelum memiliki harta warisan, Genko Sensei merupakan anak yang baik, seperti ditunjukkan data di bawah ini:

Konteks data: Sebelum menjadi pribadi buruk seperti yang di daparkan oleh konteks data sebelumnya, Genko Sensei memiliki kebiasaan yang baik. Data yang ditemukan yakni sebagai berikut:

2)この 拳固先生は、元 は正直な百 姓の児で、幼稚い時分には、ま ことに怜悧な、好い巟でありま したから、其叔父さんにも大層可 愛がられ。

Kono Genko Sensei wa, moto wa shoujiki na hyakushou no ko de, Chiisai jibun niwa, makoto ni reiri na, yoi ko de arimashita kara, sono ojisan ni mo taisou kawaigarare.

'Genko Sensei ini, pada mulanya adalah seorang anak petani yang jujur, karena pada waktu kanak-kanak ia adalah anak yang pandai, ia juga sangat disayangi oleh pamannya.'

(Dt.2/Hlm218/P2)

Dalam konteks data telah disebutkan bahwa Genko Sensei memiliki kepribadian 
yang baik sebelum mendapat harta warisan. Pada data 2 di atas dijelaskan bahwa ia merupakan anak yang jujur, baik, dan pandai sehingga membuatnya disayangi oleh pamannya. Hal tersebut ditunjukkan pada kutipan data yang digarisbawahi yakni: ... Shoujiki na hyakushou no ko de... '... Anak petani yang jujur...' serta pada kalimat yang digarisbawahi: ... Makoto ni reiri na... '... Anak yang pandai...'

Berdasarkan kedua data tersebut yakni data 7 dan data 2, dapat disimpulkan bahwa adanya faktor dari luar yaitu harta warisan yang mampu membentuk habitus tokoh utama. Habitus yang semula dimiliki tokoh utama yaitu jujur dan baik menjadi hilang dan berubah menjadi kebiasaan yang buruk. Hal tersebut membuktikan bahwa tokoh utama memiliki habitus yang dibentuk oleh hal-hal yang ada disekitarnya (Structured Structure).

\section{Habitus bersifat lentur}

Konteks data: Diceritakan bahwa Genko Sensei pada mulanya merupakan seorang anak yang giat belajar sehingga ia menjadi seorang sarjana yang terkenal. Berikut ini adalah temuan data pertama:

1)遂にはその嬉しまぎれに、学問 の方 は放较てしまって、お酒を 飲むやら、賭博を打つやら、悪い 遊興ばかりして

Tsui ni wa sono ureshi magire ni, gakumon no kata wa houkite shimatte, osake onomu yara, tobaku o utsu yara, warui yuukyou bakarishite

'Namun akhirnya, kerena terlalu gembira, ia meninggalkan kegiatan belajarnya dan meminum minumminuman keras, berjudi, dan hanya melakukan hal-hal yang buruk.'

(Dt.8/Hlm219/P5)

Dalam konteks data di atas dijelaskan bahwa tokoh utama Genko Sensei pada mulanya merupakan anak yang memiliki kebiasaan baik yakni giar belajar. Sehingga ia pun bergelar sarjana di lingkungan tempat tinggalnya.

Namun, berdasarkan paragraf pada temuan data 8 di atas, dapat dilihat bahwa muncul kebiasaan baru yang dilakukan oleh Genko Sensei yaitu mengkonsumsi minumminuman keras, berjudi, melakukan perbuatan yang buruk, bersikap egois, serta meninggalkan kegiatan belajarnya. Hal tersebut ditunjukkan pada kutipan data yang digarisbawahi yakni: ... Gakumon no kata wa houkiteshimatte, osake o nomu yara, tobaku o utsu yara, warui yuukyou bakarishite. '... Ia meninggalkan kegiatan belajarnya dan meminum minum-minuman keras, berjudi, dan hanya melakukan hal-hal yang buruk.'

Kata 'meninggalkan kegiatan belajarnya' dapat diartikan bahwa ia sebelumnya pernah memiliki kebiasaan baik yakni giat belajar (selanjutnya disebut kebiasaan pertama). Sedangkan kalimat 'meminum minuman keras, berjudi, dan hanya melakukan hal-hal buruk' dapat diartikan sebagai kebiasaan baru yang dimiliki oleh Genko Sensei (selanjutnya disebut kebiasaan kedua).

Berdasarkan paragraf tersebut dapat disimpulkan bahwa terjadi perubahan antara kebiasaan pertama dan kebiasaan kedua yang dialami oleh Genko Sensei. Perubahan tersebut membuktikan bahwa adanya sifat tidak tetap. Sifat tidak tetap ini menunjukkan bahwa habitus memiliki sifat perilaku yang lentur (dapat berubah). Sehingga dapat disimpulkan bahwa data tersebut termasuk dalam kategori habitus yang bersifat lentur.

\section{Habitus (hubungannya dengan lingkungan)}

Konteks data: Genko Sensei merupakan seseorang yang mengadakan perjanjian dengan Iblis agar ia dapat menjadi Doktor Sihir. Setelah sang Iblis mengabulkan permohonannya, Genko Sensei pun mendapatkan kekuatan sihir. Selama memiliki kekuatan sihir, ia melakukan banyak hal yang menakjubkan dengan sihirnya. Ia pun memiliki banyak teman, terutama teman- 
temannya di kedai sake. Bersama temantemannya tersebut, Genko Sensei beberapa kali menunjukkan atraksi sihirnya, salah satunya dengan kehadirannya di kedai sake meskipun teman-temannya berpendapat bahwa mustahil jika Genko Sensei dapat hadir di kedai sake yang jaraknya sangat jauh. Data yang ditemukan antara lain sebagai berikut:

1) で、友達は大勢で、お酒を飲んで 居りましたが。

De, tomodachi wa taisei de, osake o nonde orimashitaga.

'Teman-teman Sensei yang banyak itu sedang minum sake.'

(Dt.16/Hlm220/K54)

Dalam konteks di atas dijelaskan bahwa Genko Sensei adalah seorang Doktor Sihir yang mendapat kekuatan dari Iblis. Semasa memiliki kekuatan sihir, Genko Sensei memiliki banyak teman-teman yang sering menemaninya di kedai sake.

Pada temuan data 16 di atas dijelaskan bahwa Genko Sensei memiliki teman-teman. Hal tersebut ditunjukkan pada kutipan data yang digarisbawahi yakni: Tomodachi wa taisei de... 'Teman-teman Sensei yang banyak itu...' Kata 'teman-teman' bermakna lebih dari satu. Hal tersebut membuktikan bahwa tokoh utama memiliki lebih dari satu orang teman yang ia miliki. Memiliki lebih dari satu orang teman membuktikan adanya usaha dari Genko Sensei untuk menaklukkan lingkungan sosialnya sehingga terbangunlah hubungan pertemanan (intekasi) antara Genko Sensei dengan tokoh lainnya. Karena tidak mungkin seorang individu mampu mendapatkan teman banyak tanpa berinteraksi dengan lingkungan sosial masyarakatnya.

Berdasarkan analisis di atas, dapat disimpulkan bahwa data tersebut dapat dikategorikan ke dalam habitus berdasarkan struktur mental kognitif yakni hubungannya dengan lingkungan sosial. Hal tersebut dilihat dari hubungan tokoh utama dengan lingkungan sosialnya sehingga ia memiliki banyak teman.

\section{Modal}

Modal yang ditemukan dalam penelitian berjumlah 11 data, yakni sebagai berikut:

Konteks data: Genko Sensei bercita-cita menjadi seorang Doktor Sihir, ia pun mengadakan perjanjian dengan sang Iblis. Iblis pun mengabulkan permohonannya, setelah itu Genko Sensei menggunakan sihirnya dengan sewenang-wenangnya. Salah satu kisah sihir Genko Sensei adalah saat ia diundang oleh sang raja ke istana. Di istana ia mampu membuat raja kagum dengan kemampuan sihirnya. Sehingga ia pun diberi banyak hadiah oleh raja. Namun hal tersebut membuat sang menteri kerajaan menjadi iri dan melakukan segala cara untuk mengalahkan Genko Sensei. Data 31 di bawah ini adalah percakapan antara Genko Sensei dengan sang Menteri:

1) 先生: それ見た事か。ア八、、。 Sensei: Sore mita kotoka. Aaaa!

'Sensei: "Ahahaha... lihat ini! (mengeluarkan kemampuan sihirnya)", Menteri:「先生 謝謝罪った。謝罪 るからこの角を取って下さい!」 "Sensei shazatta. Shazaru kara Kono tsuno o totte kudasai!"

'Menteri: "Sensei, ampun... karena aku telah memohon ampun, tolong ambil tanduk ini!"”

(Dt.31/Hlm226/D92)

Temuan data di atas ditunjang oleh ucapan sang menteri yang terdapat dalam data di bawah ini:

2) Menteri:「さて、恐ろしい 魔法使 "だ。」

"Menteri: "Oh, ahli sihir yang mengerikan.",

(Dt.32/Hlm226/D90)

Konteks data diatas menceritakan bahwa setelah mendapatkan kekuatan sihir berkat perjanjiannya dengan sang iblis, ia pun mampu melakukan hal-hal yang mustahil dilakukan oleh manusia biasa. Salah satu kisah adalah saat ia diundang oleh sang Raja. Di istana, Genko Sensei menemui lawan 
barunya yakni sang Menteri kerajaan, di mana mereka berdua melakukan beberapa upaya atau pertarungan untuk mempertahankan dan memperluas kekuasaannya. Pertarungan terjadi dikarenakan sang menteri iri hati melihat Genko Sensei mendapatkan pujian dan banyak sekali hadiah dari sang raja, sehingga sang Menteri merasa terancam kekuasaannya di istana.

Pada data 31 di atas menjelaskan dialog Genko Sensei dengan sang Menteri. Dalam dialog tersebut terlihat bahwa Genko Sensei menggunakan sihirnya untuk melawan sang Menteri. Hal tersebut ditunjukkan pada kutipan data yang digarisbawahi yakni: Sore mita kotoka. Aaaa! 'Ahahaha... lihat ini! (mengeluarkan kemampuan sihirnya)'. Kata 'Ahahaha' di atas merupakan representasi tindakan tertawa yang dilakukan oleh Genko Sensei. Sementara kata 'Lihat ini!' menekankan pada superioritas dan keotoritasan Sensei yang mulai membuat mitra tuturnya takut terhadapnya, ditunjukkan pada kutipan data 34 yang digarisbawahi yakni: Sate osoroshii mahou tsukada. 'Oh, ahli sihir yang mengerikan.' Kalimat tersebut telah membuktikan bahwa adanya rasa ketidakpercayaan diri sang Menteri dalam melawan Genko Sensei.

Berdasarkan analisis di atas dapat diimpulkan bahwa terdapat sebuah modal simbolik yang dimiliki oleh Genko Sensei. Modal simbolik tersebut adalah kekuatan sihir yang mampu membuat posisinya dalam ranah semakin meningkat karena tidak ada yang mampu mengalahkannya sehingga membuat ia semakin berkuasa.

\section{Ranah}

Di dalam cerpen "Mahou Hakase", ditemukan data yang menunjukkan bahwa tokoh utama yakni Genko Sensei mampu menguasai ranah Universitas, Jerman, dan istana, yakni dapat dilihat dalam data berikut ini:

Konteks data: diceritakan bahwa Genko Sensei pada mulanya merupakan anak petani yang miskin, lalu ia diangkat menjadi anak angkat oleh sang paman yang sangat kaya raya. Berikut adalah temuan data di dalam cerpen:

1）学問 を勉強し、程無く立派 な学 者に_成りましたが

Gakumon o benkyoushi, hodonaku rippa na gakusha ni narimashita ga

'Ia belajar hingga menjadi seorang sarjana yang tiada tandingannya.'

(Dt.5/Hlm218/K6)

Konteks data di atas menjelaskan bahwa Genko Sensei pada awalnya merupakan anak petani yang miskin namun giat belajar dan sangat disayangi oleh pamannya.

Pada data 5 di atas diketahui bahwa Genko Sensei belajar dengan giat sehingga memiliki gelar sarjana. Hal tersebut ditunjukkan pada kutipan data yang digarisbawahi yakni: ... Gakusha... '... Sarjana...' Kata "Sarjana" dalam kalimat di atas menunjukkan bahwa ranah yang terdapat dalam cerita merupakan Universitas, karena di Universitaslah setiap orang mampu meraih gelar sarjana. Sementara kata "tiada tandingannya" menjelaskan bahwa dalam arena Universitas tersebut, Genko Sensei mampu menguasainya sehingga tak tertandingi. Pada pemaparan di atas dapat disimpulkan bahwa Genko Sensei mampu menguasa sebuah ranah yakni Universitas karena ia bergelar sarjana yang tiada tandingannya.

Sementara itu, ranah Jerman yang berhasil dikuasai oleh tokoh utama yakni Genko Sensei dapat dilihat dalam data berikut ini:

Konteks data: diceritakan bahwa Genko Sensei merupakan ahli sihir yang hebat pada zaman dahulu. Berikut adalah temuan data pada cerpen:

2)むかしどいつの国に、拳固先生 と云って、大層な魔法柄使いの 先生 が在りまました。 Mukashi doitsu no kuni ni, Genko Sensei to itte, taisou na 
mahou tsukai no Sensei ga

arimashita.

'Dahulu kala di Jerman ada seorang ahli sihir hebat yang bernama

Genko Sensei.'

(Dt.1/Hal 218/K1)

Konteks data di atas menjelaskan bahwa pada zaman dalulu pernah ada seorang ahli sihir hebat bernama Genko Sensei.

Kalimat pada data 1 di atas menjelaskan bahwa Genko Sensei dikenal dan diakui sebagai ahli sihir yang hebat di Jerman. Hal tersebut ditunjukkan pada kutipan data yang digarisbawahi yakni: ... Doitsu no kuni ni... '... Di negara Jerman...' Kata "Jerman" menunjukkan ranah, sementara kata "ahli sihir hebat" menunjukkan bahwa Genko Sensei-lah ahli sihir yang mampu menguasai ranah tersebut. Sehingga dapat disimpulkan bahwa Genko Sensei mampu menguasai ranah yang ada di Jerman.

Tidak hanya mampu menguasai ranah Universitas dan Jerman, namun Genko Sensei mampu menguasai ranah istana. Penguasaan tokoh utama terhadap ranah Istana berjumlah dua data. Data pertama dapat dilihat dalam kalimat berikut ini:

Konteks data: Genko Sensei merupakan ahli sihir yang terkenal dan mendapatkan kesempatan bertemu Raja. Berikut adalah temuan data di dalam cepen:

1) 其処で 天子様に、さう云う豪い 魔法使いなら、

Soko de tenshi you na, sau iu erai mahou tsukai nara

'Jika ahli sihir seterkenal itu, raja

ingin sekali mengundangnya ke istana.'

(Dt.28/Hlm226/K312)

Konteks data di atas menjelaskan bahwa Genko Sensei sangat tekenal pada zamannya sehingga raja mengundanganya.

Pada data 28 di atas dapat dilihat bahwa Genko Sensei mendapatkan undangan dari sang Raja ke istana. Hal tersebut ditunjukkan pada kutipan data yang digarisbawahi yakni: Soko de... 'Tempatnya sang Raja (istana)...' Usaha yang dilakukan
Genko Sensei ini mampu membuat orang lain dalam hal itu utamanya sang Raja merasa harus mengundang ahli sihir seterkenal itu, sehingga dengan diundang ke istana merupakan representasi dari upaya yang dilakukan Sensei untuk mencapai jenjang sosial yang lebih tinggi yakni di ranah istana. Upaya Genko Sensei dalam mengusai ranah istana ditunjang oleh data berikut ini:

Konteks data: Raja mengundang Genko Sensei ke istana. Di istana, Genko Sensei bertemu dengan sang Menteri kerajaan yang iri hati karena Raja memberikan banyak hadiah kepada sang Menteri. Ia dan sang Menteri pun bertarung demi memperoleh perhatian dan hadiah dari sang raja. Berikut temuan data pada cerpen:

2)さて、拳固先生は、天子様に は 御蒀美 を頂く、大臣に は降参さ せる、Sate, Genko Sensei wa, tenshi sama ni wa ohoubi o itadaku, Daijin ni wa kousan saseru, 'Sekarang, Genko Sensei telah mendapat banyak hadiah dari Raja, sang Menteri pun menyerah.'

(Dt.35/Hal 227/K339)

Konteks data di atas menjelaskan bahwa Genko Sensei tiba di istana dan mendapatkan hadiah dari sang raja. Namun Menteri kerajaan iri hati sehingga dan sang Menteri melakukan pertarungan dengan Genko Sensei.

Berdasarkan data 35 di atas dapat dilihat bahwa Genko Sensei mampu mendapatkan banyak hadiah dari Raja. Hal tersebut ditunjukkan pada kutipan data yang digarisbawahi yakni: ... Tenshisama... '... Raja...' Kata "Raja” menujukkan ranah istana, karena hanya di istanalah terdapat kehidupan Raja. Penguasaan ranah istana ditunjukkan pada kalimat taisetsun ni wa takashikousan saseru 'Ia pun juga telah membuat sang menteri Raja menyerah.' Kalimat 'sang menteri Raja menyerah' membuktikan bahwa bahwa pertarungan yang telah dijelaskan dalam konteks data di atas tentu dimenangkan oleh Genko Sensei. Berdasarkan analisis data di atas dapat disimpulkan bahwa ranah istana 
merupakan ranah yang berhasil dikuasai oleh Genko Sensei.

\section{Praktik}

Temuan praktik dalam cerpen Mahou Hakase berjumlah 16 data, yaitu sebagai berikut:

Konteks data: Di Jerman terdapat seorang ahli sihir yang terkenal bernama Genko Sensei. Namun, dahulu ia bukanlah seorang yang mengerti tentang sihir. Dahulu ia hanyalah seorang anak petani yang giat belajar. Berikut adalah data yang ditemukan:

3) 其処でそれからは、毎日一年 懸 命に成って、魔法の本を勉強し

Soko de sore kara wa, mai nichi ichi nen kenmei ni natte, mahou no hon o benkyoushi,

'Kemudian, ia mulai bersungguhsungguh setiap hari untuk mempelajari buku sihir.'

(Dt.12/Hlm219/K17)

Dijelaskan dalam konteks data tersebut bahwa ada seorang ahli sihir terkenal di Jerman bernama Genko Sensei. Dahulu ia tidak memiliki sihir dan hanyalah seorang anak petani yang sangat giat belajar.

Pada data 12 di atas menunjukan bahwa adanya usaha yang dilakukan oleh Genko Sensei untuk memperoleh keinginannya sebagai Doktor Sihir, yaitu mempelajari buku sihir setiap hari. Hal tersebut ditunjukkan pada kutipan data yang digarisbawahi yakni: ... Mai nichi ichi nen, kenmei ni natte, mahou no hon o benkyoshi. '... Bersungguh-sungguh setiap hari untuk mempelajari buku sihir.' Kata 'mempelajari' dapat didefinisikan sebagai sebuah upaya untuk mengetahui, memperdalam, dan mendapatkan suatu ilmu pengetahuan.

Ilmu pengetahuan maupun pendidikan merupakan sebuah modal yang dapat digunakan untuk memperoleh atau mencapai sesuatu yang diinginkan, sehingga dapat disimpulkan bahwa Genko Sensei mampu melakukan praktik yaitu menjadi mempelajari buku sihir untuk menjadi doktor sihir dengan memanfaatkan modal budaya yang ia miliki berupa ilmu pengetahuan yang ia pelajari dari membaca buku sihir.

Temuan praktik lainnya dapat dilihat pada data berikut ini:

Konteks data: Sebagai Doktor Sihir, Genko Sensei memiliki banyak sekali kisah saat ia menggunakan sihirnya. Salah satunya adalah pada saat ia mabuk kemudian bertengkar dengan pemilik kereta kuda yang menghalangi perjalanannya. Berikut adalah temuan data pada cerpen:

3) 思うと其の荷車を、頭から塩も付け ずに、馬ごとばり食べ初めました から、

omou to sore no basha o, atama kara shio mo tsukezu ni, uma gotobari tabesomemashita kara,

'Setelah mengatakan hal itu Sensei lalu mulai memakan kereta kuda itu dari kepala tanpa membubuhkan garam ia memakan semua bersama tulangtulangnya.'

(Dt.21/Hlm220/K149)

Pada konteks data di atas telah dipaparkan bahwa Genko Sensei menggunakan ilmu sihirnya karena terjadinya pertengkaran antara Genko Sensei yang saat itu sedang mabuk dengan pemilik kereta kuda.

Efek dari pertengkaran tersebut dapat dilihat pada data 21 tersebut yaitu Sensei memakan kereta kuda tersebut. Hal itu ditunjukkan pada kutipan data yang digarisbawahi yakni: ... Atama kara shio mo tsukezu ni, uma gotobari tabesomemashita kara. '... Sensei lalu mulai memakan kereta kuda itu dari kepala tanpa membubuhkan garam ia memakan semua bersama tulangtulangnya.'

Pada temuan data di atas Genko Sensei memiliki kekuatan sihir sehingga dapat melakukan hal yang tidak dapat dilakukan oleh manusia normal, yaitu menelan kereta kuda bulat-bulat dengan menggunakan mulutnya hinggal habis tak bersisa. Penulis mengklasifkasikan sihir sebagai modal simbolik karena mampu mendapatkan status 
dan otoritas di dalam masyarakat. Legitimasi, status, dan otoritas termasuk ke dalam modal simbolik. Jika modal digunakan oleh seseorang untuk dapat memperoleh kekuasaan dan menguasai ranah, maka hal tersebut termasuk ke dalam upaya praktik sosial dalam masyarakat. Sehingga dapat disimpulkan bahwa temuan data di atas mengandung praktik.

\section{KESIMPULAN}

Berdasarkan hasil penelitian dapat disimpulkan bahwa dalam cerpen "Mahou Hakase" karya Iwaya Sazanami ditemukan beberapa temuan habitus, modal, ranah, dan praktik pada tokoh utama Genko Sensei. Temuan tersebut antara lain, habitus sebanyak 7 temuan, modal sebanyak 11 temuan, ranah sebanyak 4 temuan, dan praktik sebanyak 16 temuan, sehingga total yang ditemukan berjumlah 38 data. Semua aspek yang disebutkan di atas yaitu habitus, modal, ranah, dan praktik saling berkaitan satu sama lain. Habitus yang ia miliki adalah relasi yang baik, dipandang baik dan jujur, serta mampu mengubah kebiasaan buruk menjadi baik. Hal tersebut ia kombinasikan dengan modal yang dimiliki berupa uang, gelar sarjana, kemampuan public speaking, tidak ragu dalam bertindak, percaya diri, kemampuan kerjasama yang baik, serta kemampuan sihir.

Dengan memanfaatkan habitus dan modal tersebut, Genko Sensei mampu melakukan banyak praktik (seperti tetap hidup meskipun tanpa kaki, menumbuhkan tanduk untuk melawan musuh, dan lainnya) sehingga dapat menguasai ranah Jerman, Universitas, dan Istana. Pada akhirnya, ia mampu menjadi terkenal, memperoleh gelar, mengalahkan musuh, memperoleh kekuasan dengan memenangkan hati Raja di Istana, serta mendapat banyak hadiah. Hal di atas selaras dengan teori Pierre Bourdieu tentang hubungan habitus, modal, dan ranah, sehingga menghasilkan praktik untuk memperebutkan kekuasaan.

\section{DAFTAR PUSAKA}

Amanda, E.N.P, 2014, “Eksistensi Diri Tokoh Genko Sensei dalam Cerpen Adaptasi Maho Hakase Karya Iwaya Sazanami. Skripsi, Fakultas Ilmu Budaya, Universitas Brawijaya.

Escarpit, Robert. 2005. Sosiologi Sastra. Jakarta: Yayasan Obor Indonesia.

Fashri, Fauzi. 2014. Pierre Bourdieu Menyingkap Kuasa Simbol. Yogyakarta: Jalasutra.

Jenkins, Richard. 2016. Membaca Pikiran Pierre Bourdieu terjemahan Nurhadi. Bantul: Kreasi Wacana.

Karnant, K.Y. 2013, "Paradigma Teori Arena Produksi Kultural Sastra: Kajian Terhadap Pemikiran Pierre Bourdieu", Jurnal Poetika, Vol. I nomor 1-2013, h.3.

Matsuura, Kenji. 1994. Kamus Bahasa Jepang-Indonesia. Kyoto: Kyoto Sanyou University Press.

Merpati, Rizky Dian, 2016, "Analisis Sosial Pada Novel 86 Karya Okky Madasari (Kajian Sosiologi Sastra Pierre Bourdieu)", Skripsi, Fakultas Ilmu Budaya, Universitas Negeri Surabaya.

Ratna, Nyoman Kutha. 2013. Teori, Metode, dan Teknik Penelitian Sastra. Yogyakarta: Pustaka Pelajar.

Ritzer dan Goodman. 2012. Teori Sosiologi Klasik-Post Modern Edisi Terbaru (Trans: Nurhadi). Yogyakarta: Kreasi Wacana.

Surastina. 2018. Pengantar Teori Sastra. Yogyakarta: Elmatera.

Thompson, John B. 2007. Language and Symbolic Power. Malden \& Cambridge: Polity Press.

Tim Guru Indonesia. 2010. Buku Pintar Pelajaran: Ringkasan Materi dan Kumpulan Rumus Lengkap. Jakarta: Wahyu Media.

Untara, Wahyu. 2013. Kamus Besar Bahasa Indonesia: Lengkap dan Praktis. Jakarta: Kawah Media.

Waluyo, Herman J. 2002. Drama: Teori dan Pengajarannya. Yogyakarta: Hanindita Graha Widya. 
Wicaksono, Andri. 2014. Pengkajian Prosa Fiksi (Edisi Revisi). Yogyakarta: Garudhawaca.

Wiyatasari, Reny. 2015. “Teknik Penerjemahan Tindak Tutur Direktif dalam Cerpen Doktor Sihir Karya Iwaya Sazanami dan Larilah Melos Karya Dazai Osamu"Jurnal Izumi, Vol. IV nomor 22015, h.42-55.
Zamzuri, Ahmad. 2016. "Bengkel Sastra Balai Bahasa DIY Dalam Perspekstif Sosiologi Pierre Bourdieu" Jurnal Paramasastra, Vol. III nomor 2-2016, h.293. 